\title{
A new dinosaur (Theropoda, Spinosauridae) from the Cretaceous (Cenomanian) Alcântara Formation, Cajual Island, Brazil
}

\author{
ALEXANDER W.A. Kellner, SERgiO A.K. AZEVEdo, Elaine B. MACHADO, \\ LUCIANA B. DE CARVALHO and DEISE D.R. HENRIQUES \\ Departamento de Paleontologia e Geologia, Museu Nacional/UFRJ, Quinta da Boa Vista s/n \\ São Cristóvão, 20940-040 Rio de Janeiro, Brasil \\ Manuscript received on November 25, 2010; accepted for publication on December 22, 2010
}

\begin{abstract}
A new spinosaurid taxon, Oxalaia quilombensis gen. et sp. nov., is described based on the anterior part of a snout and a fragment of a maxilla. These specimens were collected at the Laje do Coringa site, Late Cretaceous (Cenomanian) of the São Luis Basin. Unlike Cristatusaurus and Suchomimus, Oxalaia quilombensis lacks serrations on the teeth. The new species differs from Angaturama limai by having the anterior part of the premaxillae more expanded and by lacking a sagittal premaxillary crest. It further differs from Spinosaurus $\mathrm{cf}$. S. aegyptiacus and the Algerian spinosaurid by the rounder shape of the terminal expansion. Furthermore, Oxalaia quilombensis has one functional tooth followed by two replacement teeth, a feature not previously observed in theropods. Oxalaia quilombensis appears to be more closely related to the spinosaurids found in North Africa than to the Brazilian members of this clade and thus further increases the diversity of these enigmatic predatory dinosaurs in this country.
\end{abstract}

Key words: Dinosauria, Spinosauridae, Oxalaia quilombensis, Cenomanian, Brazil.

\section{INTRODUCTION}

Overall the dinosaur record from Brazil is extremely meager and consists mostly of isolated and incomplete remains (see Kellner and Campos 2000 for a review). In terms of non-avian theropods, other than Cretaceous footprints (e.g., Leonardi 1994) and fossilized feathers (e.g., Kellner et al. 1994), only seven species have been described so far: two from the Triassic deposits of Rio Grande do Sul whose phylogenetic position has been questioned (e.g., Galton 2000, Langer 2004, Langer et al. 2009, Bittencourt and Kellner 2009), one abelisaurid from the Late Cretaceous deposits of Mato Grosso (Gibson et al. 1997, Kellner and Campos 2002, Candeiro et al. 2006, Weska 2006) and four from the Aptian-Albian

Proceedings of the Third Gondwanan Dinosaur Symposium Correspondence to: Alexander Wilhelm Armin Kellner E-mail: kellner@mn.ufrj.br
Romualdo Formation of the Araripe Basin (Martill et al. 1996, Kellner and Campos 1996, 1999, Kellner 1999, Naish et al. 2004).

Here we report on a new theropod, Oxalaia quilombensis gen. et sp. nov., the first formally described dinosaur species from Brazilian Cenomanian (early Late Cretaceous) deposits. The remains of this taxon were collected from the locality known as Laje do Coringa at the Cajual Island, Maranhão State (Corrêa-Martins 1997). This site is one of the few bone-beds from Brazil and has yielded hundreds of isolated elements (Medeiros and Schultz 2002, Van Tomme et al. 2008), some probably reworked from previous deposits (Kellner et al. 2009). The holotype of Oxalaia quilombensis gen. et sp. nov., consisting of premaxillae (MN 6117-V), was found still in situ, a quite rare situation at the Laje do Coringa site because of the destructive effects of the 
strong tides that affect this deposit. An isolated portion of a left maxilla showing the same general features of spinosaurids is also referred to this species.

Despite being incomplete, this material shows the main characters of the theropod clade Spinosauridae and is a new addition to this bizarre and poorly known group of theropod dinosaurs.

\section{ABBREVIATIONS}

MNSM - Museo di Storia Naturale di Milano, Italy.

MN - Museu Nacional/Universidade Federal do Rio de Janeiro, Brazil.

MNHN SAM - Muséum National d'Histoire Naturelle, Paris, France.

\section{SYSTEMATIC PALEONTOLOGY}

THEROPODA Marsh 1881

SPINOSAUROIDEA Stromer 1915

sensu Sereno et al. 1998

SPINOSAURIDAE Stromer 1915

sensu Sereno et al. 1998

Oxalaia gen. nov.

Etymology: The generic name comes from Oxalá, the most respected masculine deity in the African pantheon, introduced in Brazil during slavery.

Type species: Oxalaia quilombensis sp. nov., type by monotypy.

Diagnosis: as for the type and only species.

\section{Oxalaia quilombensis sp. nov.}

Etymology: The generic name is derived from the Portuguese expression quilombo, the place where the quilombola (the descendants of former Brazilian slaves) live. The Cajual Island, where the specimens of this new taxon were collected, is one of these places.

Holotype: Fused premaxillae of a very large individual (ca. 12-14m, 5-7 tons), housed at the Museu Nacional/UFRJ under the collection number MN 6117-V (Figs. 1-3).

Referred material: Isolated and incomplete left maxilla (MN 6119-V) also collected at the Cajual Island (Fig. 4).

Locality and horizon: The holotype was collected at Laje do Coringa, on the eastern-most beach of Cajual
Island, in Maranhão State, Northeast Brazil. The rocks of this site belong to the Alcântara Formation, Itapecuru Group of the São Luís Basin whose age is regarded as Cenomanian (Late Cretaceous) (Góes and Rossetti 2001).

Diagnosis: Spinosaurid with the following combination of characters that distinguish it from other members of this clade (autapomorphies are marked with an asterisk): teeth unserrated (differing from Cristatusaurus and $\mathrm{Su}$ chomimus); maximum expansion of the distal end of the premaxillae between the 3rd and 4th alveoli*; anterior projection of the maxillae between the premaxillae in the palatal region very thin*; presence of two replacement teeth associated with the 3rd functional tooth*; diastema between the 5 th and 6 th premaxillary teeth present but shorter than in Spinosaurus; ventral portion of the premaxillae very sculptured*.

\section{DESCRIPTION AND COMPARISONS}

The preserved segment of the premaxilla (MN 6117-V) of Oxalaia quilombensis is about $201 \mathrm{~mm}$ long, $115 \mathrm{~mm}$ wide (maximum estimated width: $126 \mathrm{~mm}$ ) and $103 \mathrm{~mm}$ high (Figs. 1-3). Based on comparisons with other spinosaurids (e.g., Dal Sasso et al. 2005), the total length of the skull is estimated around $1350 \mathrm{~mm}$. This bone is broken on the region of the 7 th alveolus and, despite the fact that a second portion of an upper jaw is here tentatively referred to this taxon (MN 6119-V), the information of the posterior extension of the upper jaw in this new species is limited. The left side was partially embedded in the matrix and is the better-preserved portion (Fig. 1b). Some of the bone surface was abraded and the ventral edges that form the lateral surface of the alveoli of the right side are broken in some parts. The anterior margin of the rostrum shows some large and deep pits interpreted as neurovascular foramina. A row of nutrient foramina just above the bases of the teeth on the left side is observed.

The premaxilla has seven alveoli, the last one incompletely preserved on both sides (Fig. 2). This is the same number as found in Angaturama, Suchomimus, the Algerian spinosaurid (MNHN SAM 124) and Cristatusaurus (Kellner and Campos 1996, Taquet and Russell 1998, Sereno et al. 1998), but differs from the upper jaw 

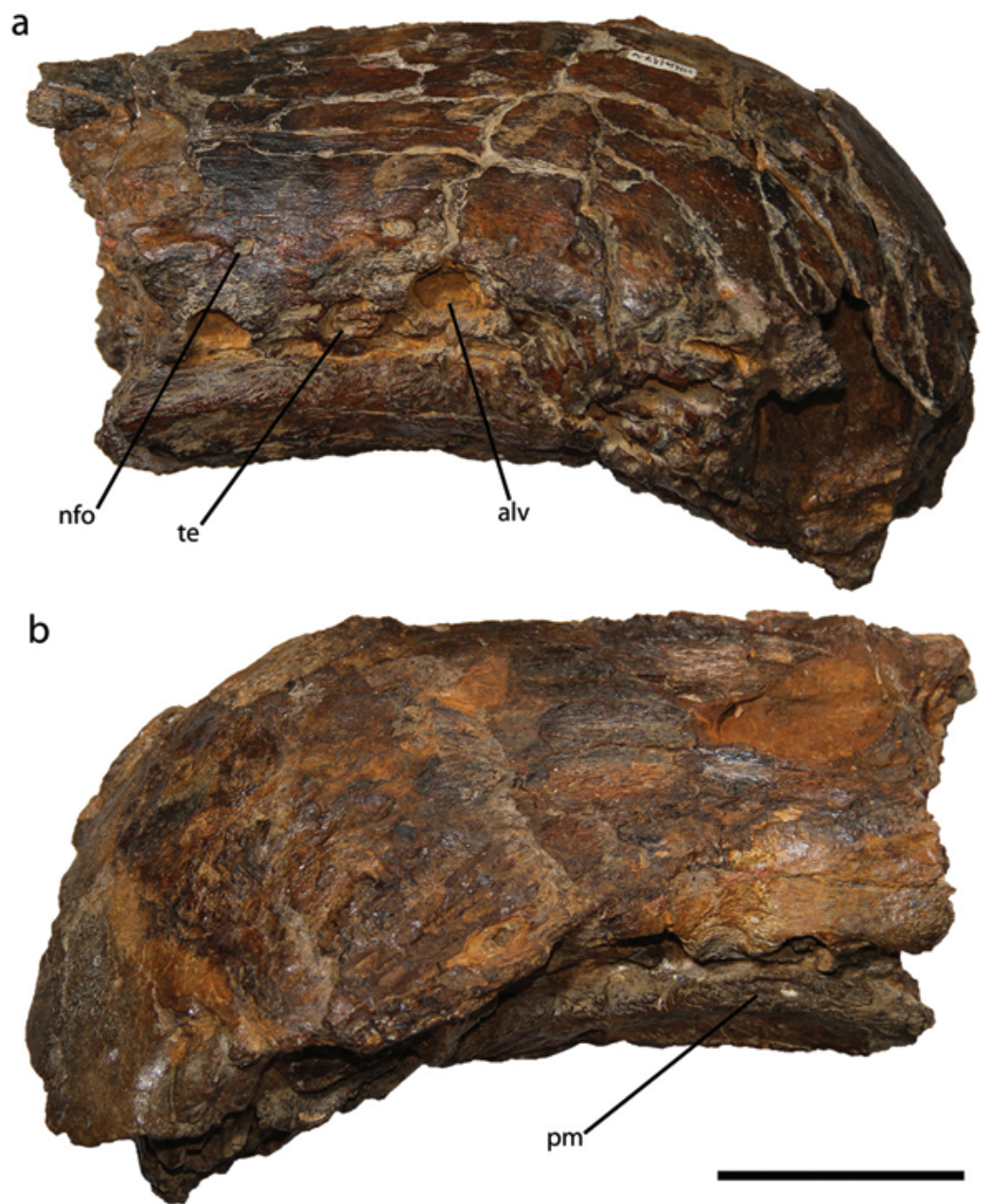

Fig. 1 - Oxalaia quilombensis gen. et sp. nov. (MN 6117-V). a - right lateral view; b - left lateral view. Abbreviations: alv - alveolus; nfo nutritive foramen; $\mathbf{p m}$ - premaxilla; te - tooth. Scale bar: $50 \mathrm{~mm}$.

attributed to Spinosaurs cf. S. aegyptiacus by Dal Sasso et al. (2005), in which only six premaxillary teeth were found. There is a marked variation in the teeth size, with the first one (incompletely preserved) rather small, and the 2 nd and 3rd alveoli being the largest. One marked diastema separating the 3rd from the 4th tooth is observed, which is present in all other spinosaurids, being smaller in Suchomimus. A second diastema between the 5th and the 6th alveoli is also observed in Oxalaia, similar to the Algerian spinosaurid (MNHN SAM 124, Taquet and Russell 1998). This diastema is absent in Suchomimus and Cristatusaurus and is much longer in Spinosaurus cf. Spinosaurus aegyptiacus described by Dal Sasso et al. (2005).

The anterior part is very expanded, forming the typical spinosaurid rosetta, being most constricted be- tween the 6th and 7th alveoli. This terminal expansion of Oxalaia is similar to that observed in Suchomimus and Cristatusaurus by having the lateral margins getting gradually thinner posteriorly, lacking the small constriction present between the 3rd and 4th alveoli in the Algerian spinosaurid (MNHN SAM 124) and Spinosaurus cf. $S$. aegyptiacus that in those taxa give the anterior portion of the rosetta a rather triangular shape (Dal Sasso et al. 2005: Fig. 1b, Taquet and Russell 1998: Fig. 1a).

Ventrally, the maxillae extend anteriorly, forming two elongated processes that are encased laterally by the premaxillae. These rostral extensions of the maxillae, which border a triangular opening, are rather thin and less exposed ventrally compared to other spinosaurids (e.g., Suchomimus, the Algerian spinosaurid, Cristatusaurus). The bone surface of this portion of the premax- 


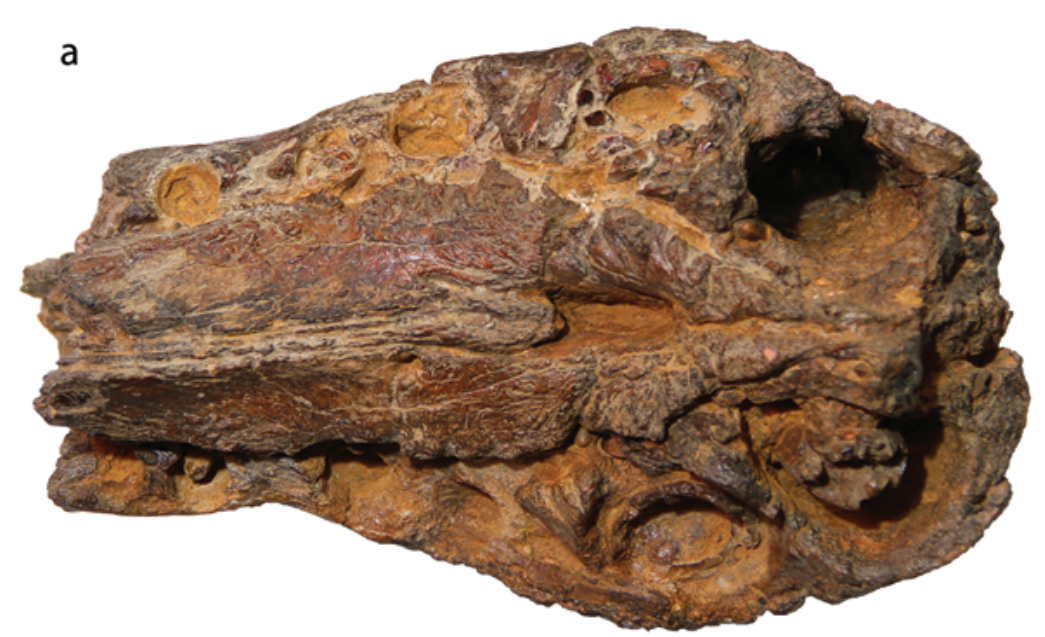

b

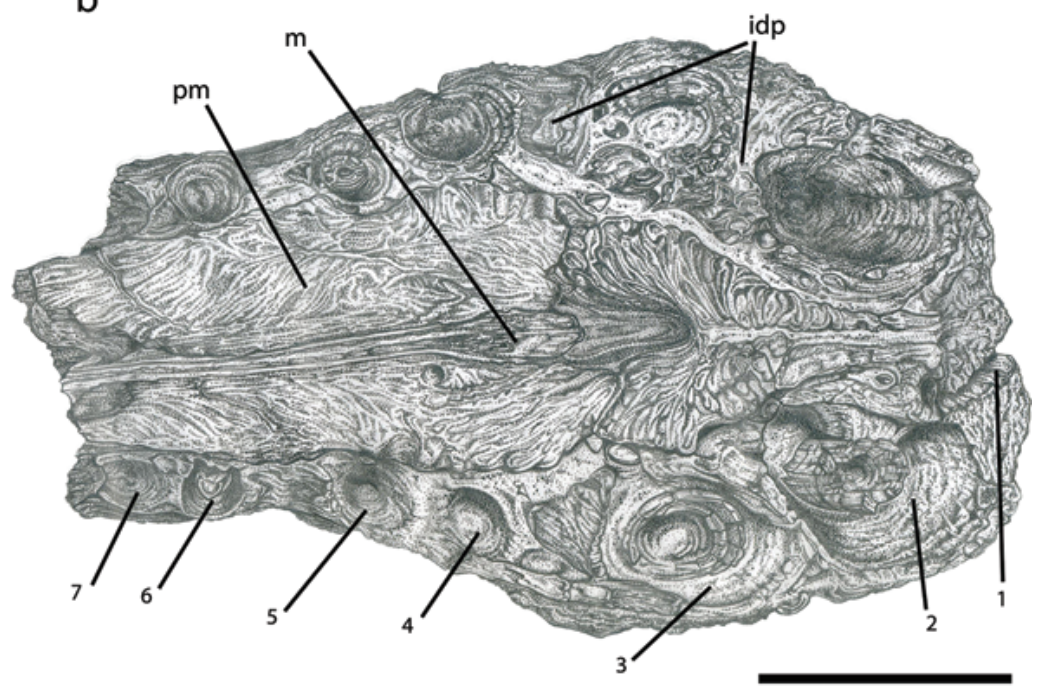

Fig. 2 - Oxalaia quilombensis gen. et sp. nov. (MN 6117-V) in ventral view. a - holotype; b - drawing of the holotype. Abbreviations: idp interdental plate; $\mathbf{m}$ - maxilla; $\mathbf{p m}$ - premaxilla; 1 to 7 - numbers of alveoli. Scale bar: $50 \mathrm{~mm}$.

illae is well ornamented, differing from the smoother condition observed in other spinosaurids.

Except for the replacement teeth, no tooth shows the apical portion of the crown. Teeth fragments are present in the 3rd and 5th alveoli of the right side and in the 2nd and 3rd alveoli of the left side. All preserved portions lack serrations. Where observable, the teeth are not lateromedially compressed as in other theropods (e.g., Currie et al. 1990), but show an oval transverse section, a typical feature of spinosaurid teeth (e.g., Stromer 1915, Kellner and Mader 1997). In the 3rd alveolus of each side, two replacement teeth are present, an unusual feature within theropods (Fig. 3a). Other replacement teeth are found in the 1st, 2nd, 3rd and 6th alveoli of the left side and on the 2nd and 3rd of the right side. The more apical section of the crown of the replacement teeth is straight, slightly flattened labiolingually. The interdental plates are prominent especially between the 2nd and 3rd; and 3rd and 4th alveoli.

The second specimen referred to Oxalaia quilombensis gen. et sp. nov. is the fragment of a left maxilla (MN 6119-V), containing two complete alveoli and part of a 3rd one (Fig. 4). The specimen was found as surface float, a common condition of the fossils in this deposit (e.g., Kellner et al. 2009), and shows extensive abrasion on the lateral side, with the medial side well preserved. The last alveolus bears fragments of a broken tooth. A shallow depression is present on the dorsal side, which 

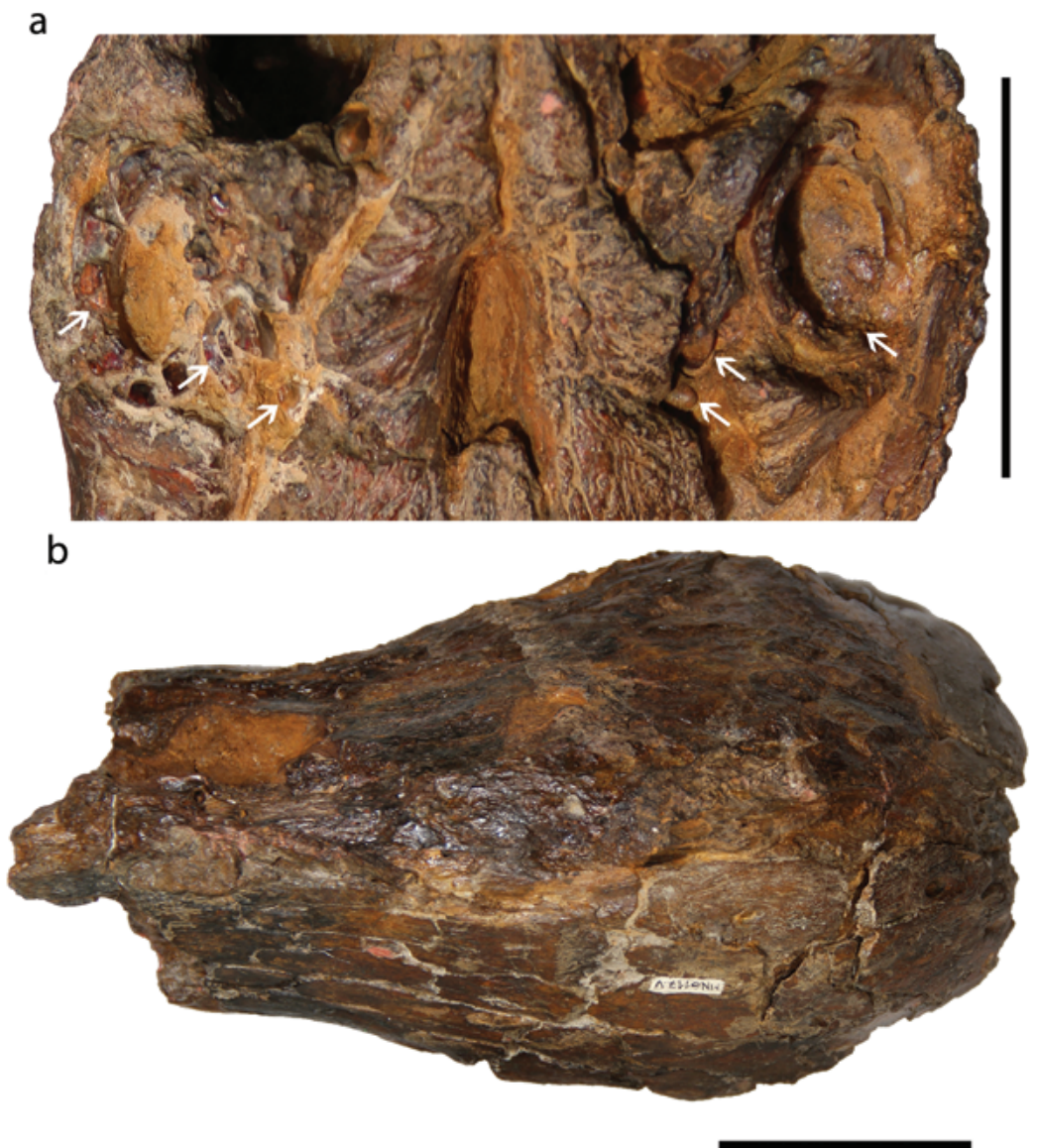

Fig. 3 - Oxalaia quilombensis gen. et sp. nov. (MN 6117-V). a - ventral view, showing the replacement teeth in the 3rd alveolus; $\mathbf{b}$ - dorsal view. Arrows indicate the larger functional and the smaller replacement teeth. Scale bar: $50 \mathrm{~mm}$.

suggests that this specimen was likely forming part on the posterior end of the external naris. A row of nutritive foramina above the base of the teeth is also preserved on the lateral surface of this bone.

\section{DISCUSSION}

Overall spinosaurids are one of the less well-known groups of theropod dinosaurs. Introduced in the literature by Stromer (1915), all specimens of Spinosaurus aegyptiacus collected in the early Cenomanian Baharija Formation of Egypt were destroyed during the Second World War (Taquet 1984). No upper jaw was present in the material originally described (Stromer 1915, Kellner and Campos 1996), and therefore no direct comparison between jaw elements of this species and Oxalaia quilombensis is possible (although both have teeth with unserrated carinae). Dal Sasso et al.
(2005) have referred a partial skull found in early Cenomanian strata of Morocco to Spinosaurus cf. $S$. aegyptiacus. Providing this assignment is correct, the Moroccan species has only 6 premaxillary teeth against 7 present in all other spinosaurids (including Oxalaia quilombensis) which might be a diagnostic feature of this taxon. Another plausible explanation for the reduced number of premaxillary teeth in Spinosaurus cf. S. aegyptiacus (MSNM V4047) is ontogeny, based on the fact that some reptiles tend to loose one or two teeth as they grow older (e.g., recent crocodylomorphs, Tyrannosaurus rex). However, due to the lack of a considerable sample size which is paramount in determining individual and ontogenetic variations (e.g., Kellner 2010), the reduction of premaxillary teeth as a function of ontogeny cannot be definitively confirmed in spinosaurids at this time. Other differences between Oxalaia quilombensis and Spinosaurus cf. S. aegyptiacus include 


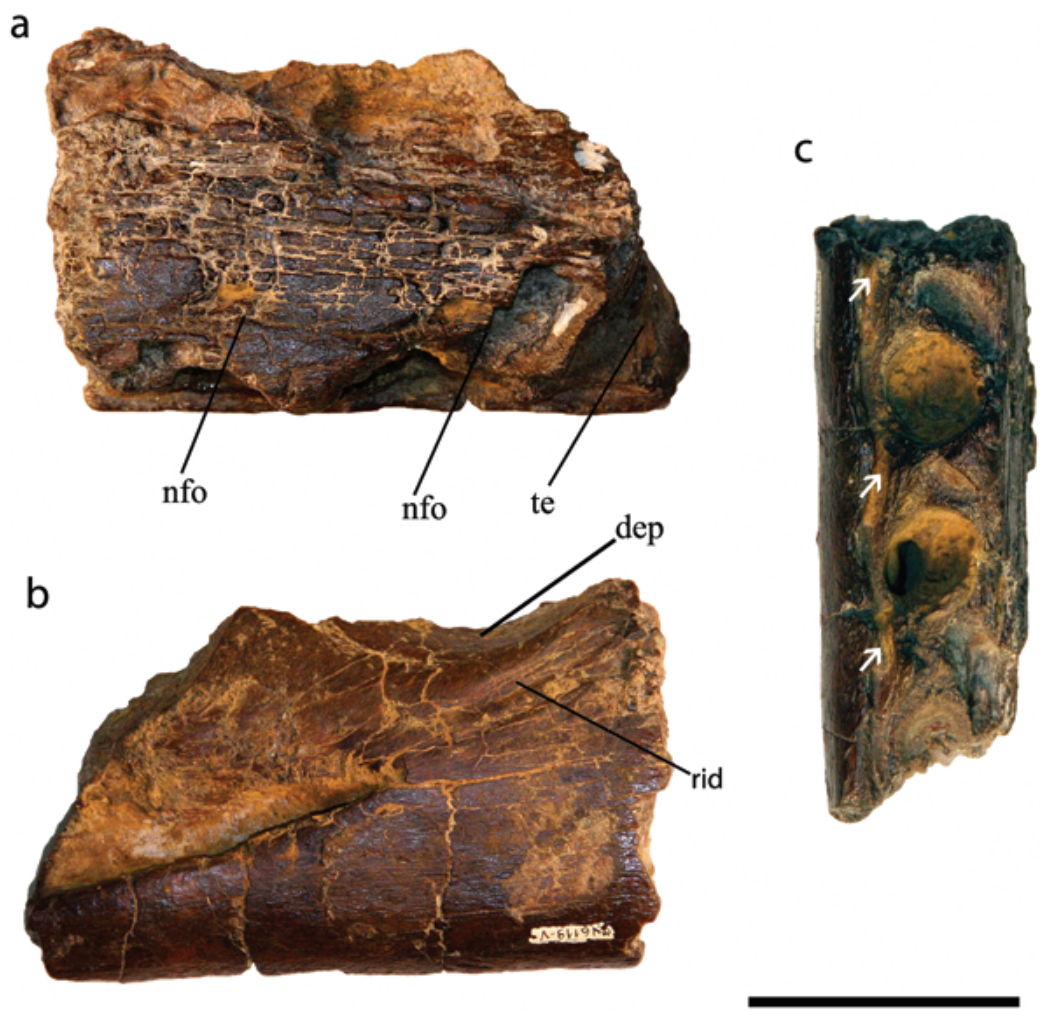

Fig. 4 - Oxalaia quilombensis gen. et sp. nov. (MN 6119-V), fragment of the left maxilla. a - in lateral view; $\mathbf{b}-$ in medial view; $\mathbf{c}-$ in ventral view. Abbreviations: dep-depression; nfo-nutritive foramen; rid - ridge; te - tooth. Arrows indicate the channel that ends inside the medioposterior part of the alveoli. Scale bar: $50 \mathrm{~mm}$.

the spacing of the alveoli, much larger in the latter, and the small constriction between the 3rd and 4th alveoli of the Moroccan taxon, giving the anterior portion of the rosetta a rather triangular shape in dorsal view (see description).

A second taxon, Spinosaurus maroccanus from supposed Albian deposits of Morocco, was erected by Russel (1996) based on one cervical vertebra whose centrum is quite elongated. This species was considered by Sereno et al. (1998) and Dal Sasso et al. (2005) as nomen dubium. Taquet and Russell (1998) referred an incomplete rostrum collected in Albian deposits of Algeria to Spinosaurus maroccanus, but since there is no material in common that would allow a detailed comparison, this allocation is questionable and we refer to MNHN SAM 124 as the Algerian spinosaurid. In any case, Oxalaia differs from the latter by the thinner anterior projection of the maxillae and the strongly ornamented ventral surface of the premaxillae. Furthermore, as in Spinosaurus cf. S. aegyptiacus, the anterior por- tion of the rosetta in the Algerian spinosaurid has a triangular shape in dorsal view.

Differences between Oxalaia quilombensis and the Baryonychinae (sensu Sereno et al. 1998) - a clade that includes Baryonyx walkeri, Cristatusaurus lapparenti and Suchomimus tenerensis - are the teeth with serrated carinae and the absence of a marked diastema between the 5th and 6th alveoli (Charig and Milner 1986, 1997, Taquet and Russell 1998, Sereno et al. 1998). Besides these, Oxalaia quilombensis bears two replacement teeth in the 3rd alveoli, an unusual feature that, to our knowledge, is here reported for the first time in theropods.

Two additional spinosaurid dinosaurs were described from Brazil, both from the Albian Romualdo Formation of the Santana Group: Irritator challengeri and Angaturama limai. Based on different portions of the skull, the specimens on which these taxa are based do not represent the same individual (contra Sereno et al. 1998, see Machado and Kellner 2005). Detailed 
comparisons of the new species with Irritator that lacks the anterior end of the rostrum (Sues et al. 2002) cannot be made. Regarding Angaturama limai, Oxalaia quilombensis differs from this taxon by the lack of a sagittal crest and by having a wider rostrum, among others. Other spinosaurid material from the Romualdo Formation, consisting of vertebrae (Bittencourt and Kellner 2004) cannot be compared with the new species described here.

Based on the morphology of the rostrum and the dentition, two main groups of Spinosauridae can be recognized (e.g., Kellner and Campos 1996, Sereno et al. 1998). The Baryonychinae share teeth with finely serrated carinae, posterior end of the terminal rosetta less constricted than in spinosaurins, and lack a marked diastema between the 5th and 6th alveoli. The monospecific Cristatusaurus and Suchomimus are very similar and came from the same deposit, raising the possibility that they are congeneric or even conspecific, in which case Cristatusaurus lapparenti has priority over Suchomimus tenerensis.

The second group, the Spinosaurinae, is united by the unserrated carinae, a very unusual feature within theropods. They also show a comparatively smaller first premaxillary pair of teeth and a larger spacing in the upper jaw (and, where observable, also in the lower jaw, Sereno et al. 1998). Within spinosaurins, Spinosaurus cf. Spinosaurus aegyptiacus and the Algerian spinosaurid (found in deposits of different age - Cenomanian and Albian, respectively) apparently are closely related in respect to Oxalaia quilombensis, which is based on the particular triangular shape of the rostral end. Also part of the spinosaurin clade is Angaturama limai that differs from the new species described here by having a sagittal crest and a comparatively more compressed rostrum (features also possibly present in Irritator challengeri, see Machado and Kellner 2005). Morphologically, Angaturama (and likely Irritator) is very distinct from other spinosaurins and perhaps represents a different group of spinosaurid theropods.

From the same deposits of Oxalaia quilombensis, Medeiros (2006) reported the presence of hundreds of spinosaurid teeth that he classified into two main morphotypes. Morphotype 1 shows the typical spinosaurin teeth with unserrated carinae, fluted and rounded trans- verse section. Morhotype 2 also has the general aspect of spinosaurin teeth (e.g., unserrated carinae, slightly labiolingually compressed) but presents the tooth enamel smooth. Although fragmentary, the dentition observed in Oxalaia quilombensis, compares well with the morphotype 1 of Medeiros. The specimens of morphotype 2 apparently show a broad range of variations, particularly regarding compression, and represent either worn teeth of morphotype 1 or do indeed indicate a yet undescribed spinosaurin theropod in those deposits, as Medeiros (2006) supposed.

Several typical spinosaurid teeth have been found in other stratigraphic units, some mistaken as belonging to crocodylomorphs (see Buffetaut 2010 for a historical review). In Brazil, Candeiro et al. (2004) referred some isolated teeth from the Bauru Basin to this clade and latter Candeiro et al. (2006: fig.12c) dismissed this occurrence but still labeled one tooth as Spinosauridae. Compared to published spinosaurid teeth (e.g., Kellner and Mader 1997, Sereno et al. 1998, Medeiros 2006), this material most likely belongs to crocodyliforms, as has been pointed out before (Machado et al. 2008). Salgado et al. (2009) reported one tooth from the Cerro Lisandro Formation (lower Turonian, Early Cretaceous) as possible referable to the Spinosauridae. However, despite the fluting and the oval transverse section, this tooth is rather unusual for spinosaurids in being small and by having coarsely serrated carinae, contrary to what is reported in the Baryonychinae (e.g., Sereno et al. 1998). Although any assessment is difficult without cranial material, the Lisandro specimen either belongs to a quite distinctive spinosaurid or to a bizarre crocodylomorph, the latter being favored here.

Comparisons between the premaxillae of $O x a$ laia quilombensis and Spinosaurus cf. S. aegyptiacus (MSNM V4047) suggest that the new Brazilian spinosaurid had a total length between 12 and 14 meters and a mass of 5 to 7 tons, making it the largest theropod recovered from the country so far.

\section{CONCLUSIONS}

Although mainly known from the premaxillae (MN 6117-V), Oxalaia quilombensis is clearly assignable to the Spinosauridae based on its dentition, number of premaxillary teeth and the shape of the rostrum. Despite 
its incompleteness, the material further shows a distinct morphology from other spinosaurids and comes from a distinct deposit, which is located in a different geographical area from other spinosaurid occurrences, criteria regarded as determinant for the recognition of a new species in the fossil record (see discussion in Kellner 2010).

Regarding the phylogenetic position, Oxalaia quilombensis is part of the Spinosaurinae, closely related to Spinosaurus cf. Spinosaurus aegyptiacus and the Algerian spinosaurid (Dal Sasso et al. 2005, Taquet and Russell 1998). It is further the largest theropod recovered from Brazil so far and demonstrates that this clade of bizarre theropods was present on the coastal area of the country from the Albian (e.g., Angaturama) to the early Cenomanian.

\section{ACKNOWLEDGMENTS}

Gareth Dyke (University College Dublin, Ireland) and Jonathas de Souza Bittencourt (USP, Ribeirão Preto) are thanked for comments on earlier drafts of the ms. We thank the Conselho Nacional de Desenvolvimento Científico e Tecnológico (CNPq, grant number 307276/ 2009-0 to AWAK) and Fundação Carlos Chagas Filho de Amparo à Pesquisa do Estado do Rio de Janeiro (FAPERJ, grant number E-26/102.779/2008 to AWAK) that partially funded this project. The drawing of the type-specimen was done by André Pinheiro (Instituto de Geociências, UFRJ). We would also like to acknowledge João Nogueira and Leonardo Eddie (Rio de Janeiro) for support during the development of this project.

\section{RESUMO}

Um novo espinossaurídeo, Oxalaia quilombensis gen. et sp. nov., é descrito com base na parte anterior de um rostro e de um fragmento da maxila. Os espécimes são procedentes do depósito Laje do Coringa, formado durante o Cretáceo Superior (Cenomaniano) da Bacia de São Luis. Ao contrário de Cristatusaurus e Suchomimus, Oxalaia quilombensis não possui dentes serrilhados. A nova espécie difere de Angaturama limai pela ausência de crista sagital e por possuir a região do rostro mais expandida. Também difere de Spinosaurus cf. S. aegyptiacus e do espinossaurídeo da Argélia pelo rostro mais arredondado. Além disso, Oxalaia quilombensis possui dois dentes de substituição no terceiro par de dentes pré- maxilares, uma feição até então desconhecida em terópodes. Oxalaia quilombensis está aparentemente mais proximamente relacionado aos espinossaurídeos da região norte da África do que às formas brasileiras e aumenta a diversidade deste grupo enigmático de dinossauros predadores no país.

Palavras-chave: Dinosauria, Spinosauridae, Oxalaia quilombensis, Cenomaniano, Brasil.

\section{REFERENCES}

Bittencourt JS AND Kellner AWA. 2004. On a sequence of sacrocaudal theropod dinosaur vertebrae from the Lower Cretaceous Santana Formation, northeastern Brazil. Arq Mus Nac 62: 309-320.

BitTencourt JS AND Kellner AWA. 2009. The anatomy and phylogenetic position of the Triassic dinosaur Staurikosaurus pricei Colbert, 1970. Zootaxa 2079: 1-54.

Buffetaut E. 2010. Spinosaurs before Stromer: early finds of spinosaurid dinosaurs and their interpretation. In: Moody R, Buffetaut E, Naish D And Martill D (Eds), Dinosaurs and Other Extinct Saurians: A Historical Perspective. Geol Soc, London, Spec Publ 343: 175-188.

Candeiro CRA, Abranches CT, Abrantes EA, AvilLA LS, MARTins VC, Moreira AL, TORRES SR AND BERGQVist LP. 2004. Dinosaurs remains from western São Paulo state, Brazil (Bauru Basin, Adamantina Formation, Upper Cretaceous). J South Am Earth Sci 18: 1-10.

CANDEiro CRA, Martinelli AG, Avilla LS AND Rich TH. 2006. Tetrapods from the Upper Cretaceous (Turonian-Maastrichtian) Bauru Group of Brazil: a reappraisal. Cretaceous Res 27: 923-946.

Charig AJ And Milner AC. 1986. Baryonyx, a remarkable new theropod dinosaur. Nature 324: 359-361.

Charig AJ AND Milner AC. 1997. Baryonyx walkeri, a fish-eating dinosaur from de Wealden of Surrey, Bull Nat Hist Mus, Geology Series 53(1): 11-70.

CorrêA-Martins FJ. 1997. A Laje do Coringa: um bonebed da Formação Itapecuru (Cretáceo Superior da Bacia de São Luís - MA). An Acad Bras Cienc 63(3): 436-437.

CURRIE PJ, RigBY JK JR AND SLOAN RE. 1990. Theropod teeth from the Judith River Formation of southern Alberta, Canada, p. 107-125. In: CARPENTER K AND CURRIE PJ (Eds), Dinosaur Systematics: Perspectives and Approaches. Cambridge University Press, Cambridge.

Dal Sasso C, Maganuco S, Buffetaut E and MenDEZ MA. 2005. New information on the skull of the enigmatic theropod Spinosaurus, with remarks on its size and affinities. J Vert Paleont 25: 888-896. 
GALton PM. 2000. Are Spondylosoma and Staurikosaurus (Santa Maria Formation, Middle-Upper Triassic, Brazil) the oldest saurischian dinosaurs? Paläont Zeit 74: 393423.

Gibson SA, THOMPSON RN, WESKA RK, DiCKIN AP AND LEONARdos OH. 1997. Late Cretaceous riftrelated upwelling and melting of the Trindade starting mantle plume head beneath western Brazil. Contr Mineral Petrol 126: 303-314.

Góes AM And Rossetti DF. 2001. Gênese da Bacia de São Luís-Grajaú, meio norte do Brasil. In: RosSetTi DF, Góes AM AND TRUCKenbrodt W (Eds), O Cretáceo na Bacia de São Luís-Grajaú. Belém, Museu Goeldi, p. 15-30.

Kellner AWA. 1999. Short note on a new dinosaur (Theropoda, Coelurosauria) from the Santana Formation (Romualdo Member, Albian), Northeastern Brazil. Bol Mus Nacl, Geol 49: 1-8.

Kellner AWA. 2010. Comments on Pteranodontidae with the description of two new species. An Acad Bras Cienc 82: 1063-1084.

Kellner AWA And CAmpos DA. 1996. First Early Cretaceous theropod dinosaur from Brazil with comments on Spinosauridae. N Jahr Geol Palaeont Abh 199(2): 151166.

Kellner AWA and Campos DA. 1999. Vertebrate paleontology in Brazil - a review. Episodes 22: 238-251.

Kellner AWA And CAmpos DA. 2000. Brief review of dinosaur studies in Brazil. An Acad Brasil Cienc 72: 509538.

Kellner AWA AND CAmpos DA. 2002. On a theropod dinosaur (Abelisauria) from the continental Cretaceous of Brazil. Arqui Mus Nac 60: 163-170.

Kellner AWA AND Mader BJ. 1997. Archosaur teeth from the Cretaceous of Morocco. J Paleont 71: 525-527.

Kellner AWA, Maisey JG and Campos DA. 1994. Fossil down feather from the Lower Cretaceous of Brazil. Paleontology 37: 489-492.

Kellner AWA, Pinheiro AEP, Azevedo SAK, HenRiQues DDR, CARVAlho LB AND Oliveira G. 2009. A new crocodyliform from the Alcântara Formation (Cenomanian), Cajual Island, Brazil. Zootaxa 2030: 4958.

LANGER MC. 2004. Basal Saurischians. In: WEISHAMPEL DB, Dodson P, Osmólska H (Eds), The Dinosauria, Second edition. Berkeley: University of California Press, p. $25-46$.
LANGER MC, EZCURRA MD, BITTENCOURT JS AND Novas FE. 2009. The origin and early evolution of dinosaurs. Biol Rev 84: 1-56.

LEONARDi G. 1994. Annotated atlas of South America tetrapod footprints (Devonian to Holocene). Companhia de Pesquisa e Recursos Minerais - CPRM, Brasília, 247 p.

Machado EB, Campos DA And Kellner AWA. 2008. On a theropod scapula (Upper Cretaceous) from the Marília Formation, Bauru Group, Brazil. Paläont Zeit 82: 308-313.

Machado EB And Kellner AWA. 2005. Notas sobre Spinosauridae (Theropoda, Dinosauria). An Inst Geoc UFRJ 28: 158-173.

Martill DM, Cruickshank ARI, Frey E, SMall PG AND ClARKE M. 1996. A new crested maniraptoran dinosaur from the Santana Formation (Lower Cretaceous) of Brazil. J Geol Soc London 153: 5-8.

Medeiros MA. 2006. Large theropod teeth from the Eocenomanian of northeastern Brazil and the occurrence of Spinosauridae. Rev Brasil Paleont 9: 333-338.

Medeiros MA And Schultz CL. 2002. A fauna dinossauriana da Laje do Coringa, Cretáceo médio do Nordeste do Brasil. Arq Mus Nac 60: 155-162.

NAish D, MArtill DM And Frey E. 2004. Ecology, Systematics and Biogeographical Relationships of Dinosaurs, Including a New Theropod, from the Santana Formation (?Albian, Early Cretaceous) of Brazil. Historical Biology 16: $57-70$.

RUSSEL DA. 1996. Isolated dinosaur bones from the Middle cretaceous of the Tafilalt, Morocco. Bull Muséum National d'Historie Naturelle 4: 349-402.

Salgado L, CANudo Ji, Garrido AC, Ruiz-OMEÑaCA JI, GARCía RA, FuENTE MS, BARCO JL AND BolLATI R. 2009. Upper Cretaceous vertebrates from El Anfiteatro area, Río Negro, Patagonia, Argentina. Cretaceous Res 30: 767-784.

SERENO PC ET AL. 1998. A long snouted predatory dinosaur from Africa and the evolution of Spinosaurids. Science 282: 1298-1302.

Stromer E. 1915. Ergebnisse der Forschungsreisen Prof. E. Stromer in den Wüsten Agyptens. II. Wirbeltier-Reste der Baharîje-Stufe (unterstes Cenoman). 3. Das Original des Theropoden Spinosaurus aegyptiacus nov. gen., nov. spec. Abhandlungen der Königlich Bayerischen Akademie der Wissenschaften, Mathematisch-Physikalische 28(3): 1-32. 
Sues HD, Frey E, Martill DM And Scott DM. 2002. Irritator challengeri, a spinosaurid (Dinosauria: Theropoda) from the Lower Cretaceous of Brazil. J Vert Paleont 22: $535-547$.

TAQUET P. 1984. Une curieuse spécialisation du crâne de certains Dinosaures carnivores du Crétacé: le museau long et étroit des Spinosauridés. CR Acad Sci (Paris) 299: 217222.

TAquet P AND Russell DA. 1998. New data on spinosaurid dinosaurs from the Early Cretaceous of the Sahara. CR Acad Sci (Paris) 327: 347-353.
VAN TOMME MPA, MEDEIROS MA AND MACHADO EB. 2008. On an enigmatic theropod tibia from the Alcântara Formation (Late Cretaceous, Early Cenomaniam) of Maranhão, NE Brasil, p. 199-200. In: Boletim DE RESUMOS DO VI SIMPÓSIO BRASILEIRO DE PALEONtologia de Vertebrados. Paleontologia em Destaque, boletim especial.

WESKA RJ. 2006. Uma síntese do Cretáceo Superior matogrossense. Geociências 25: 71-81. 